\section{Sir George Beilby Memorial Award, 1956}

The Administrators of the Sir George Beilby Memorial Fund, representing the Institute of Metals, the Royal Institute of Chemistry and the Society of Chemical Industry, have made an award of one hundred and fifty guineas to Mr. R. W. Kear in recognition of his work on the behaviour of fuel impurities in combustion processes, with special reference to the role of sulphur, chlorine and alkalis in corrosion and deposit formation by flue gases in combustion appliances. Mr. Kear, who joined the British Coal Utilization Research Association in 1946 , became head of the Corrosion Section early in 1954 and was a member of the technical and advisory panel of the Boiler Availability Committee. Although his work was primarily concerned with power station boilers, he has also made contributions to the development of the solid-fuel fired gas turbine and to the problem of atmospheric pollution. He has recently left the British Coal Utilization Research Association and joined the Oil Products Development Depart. ment of the Shell Petroleum Company, Ltd.

\section{Guided Missiles Range in the Hebrides}

REPLYING to a question in the House of Lords on February 27 regarding the guided-missile range in the Hebrides, Lord Mancroft, Parliamentary Secretary to the Ministry of Defence, said that the precise scope of the Guided Weapons Establishment has not been finally determined, but about 3,000 persons might be employed in connexion with its construction. Lord Mancroft assured Lord Elibank that, apart from any necessary security regulations, there would be no interference with the public right of entry into South Uist, Benbecula and North Uist, and that the Service authorities on all the islands would have constant regard to the safeguarding, so far as is possible, of the interests of the crofting communities, the elements of Gælic culture and all the rare bird life on the islands. Pressed further, particularly in regard to archrological finds at West Gerinish in South Uist and at a site in North Uist near the end of the proposed runway at Sollas, Lord Mancroft stated in reply to a comment by the Earl of Hadding ton that every possible attention would continue to be paid to the needs of archæologists in this area; and in reply to Lord Seltoun he undertook to look carefully once more into the question of a local inquiry in connexion with the proposed range.

\section{Centenary of the Chemical Inspectorate}

UNDER the title "Chemical Service in Defence of the Realm", the Ministry of Supply has published an account by W. G. Norris of the work of the Chemical Inspectorate during the past hundred years (pp. $91+12$ plates. Kidbrooke, London: Ministry of Supply, Chemical Inspectorate, 1957). Originally formed in 1854 at Woolwich Arsenal as an establishment of the War Department, the Chemical Inspectorate, which has had five changes of name during its century of service, is one of the oldest Government scientific establishments. To-dry, it is one of seven specialist inspectorates maintained by the Ministry to help control the quality and serviceability of its vast range of stores, but it has retained its original function as the inspection authority for all military stores and materials the serviceability of which can be assessed primarily by chemical means. To-day this work, besides the maintenance of standards of quality, includes the compiling of Service specifications, and the development of new and improved analytical techniques and apparatus. It also provides a comprehensive analytical service available not only throughout the Ministry of Supply but also to other Government Departments, such as the Board of 'Trade, the Ministry of Health, the Home Office and the Ministry of Works. Some of its recent analytical work is described in a final chapter, in which special stress is laid on the value of its work on penicillin and on materials for the production of nuclear energy outside the military field.

\section{Higher Education in the United Kingdom}

Althoбgh the United Kingdom attracts overseas students in thousands, there is no central agency by which applicants can be selected and appropriately placed in colleges or universities, since these institutions are independent academic bodies enjoying the right to set their own entrance standards and make their own choice of students. This presents a difficult problem for the overseas student who is eager to study or be trained in research in Great Britain and yet does not know in what institutions the subject of his choice is pursued, or by what means he can gain entry to them. To help him, the British Council, in conjunction with the Association of Universities of the British Commonwealth, has prepared a book (5s. net) giving the names and addresses of the in. stitutions, what they do, what their minimum entry requirements are, and approximately what fees they charge. That should enable the prospective student to decide in advance in which of them he would like, or might be able, to study. Although compiled for the overseas students, the book should prove equally valuable to British students and would be useful to all who have to adviso young men who wish to study at institutions of higher education.

\section{The Imperial College Charter Jubilee}

The Imperial College of Science and Technology celebrates this year the Jubilee of its establishment in July 1907 by Royal Charter, which brought about the federation in the new Imperial College of three colleges of earlier origin-the Royal Colloge of Science, the Royal School of Mines and the City and Guilds College. In the forefrent of the Charter Jubilee celebrations will be the visit of H.M. Queen Elizabeth the Queen Mother, as Chancellor of the University of London, on May 28, when Her Majesty will open the Roderic Hill building for aeronautics and chemical engineering. This is the first major building project to be completed in the massive expansion programme undertaken by the College in 1953 at the request of the Government. The Marquess of Salisbury, Lord President of the Council, is to be the guest of honour at the Jubilee dinner to be held at the Mansion House on May 27.

\section{Operational Research and Cybernetics}

WrTH the aim of advancing the latest managerial techniques of control, the United Steel Companies, Ltd., are to establish a new department of operational research and cybernetics. Based in Sheffield, the department will serve all the branches of United Steel with advice on operational research problems, and will provide the personnel to carry out its proposals. Initially, the department will have a staff of about twenty-five research workers, including biologists, physicists, psychologists, engineers, economists, mathematicians and logicians. Mr. Stafford Beer, formerly production controller at Samuel Fox 